\title{
"Uncertainty" and the Keynesian Revolution
}

\author{
E. Roy Weintraub
}

\section{Introduction}

In this article I would like to examine one innovation that Keynes introduced into economics with The General Theory of Employment, Interest and Money, namely, the relationship of uncertainty to investment. In Section II I shall argue that this theme had existed in Keynes' writings as early as 1908 and was essential to his main thesis of $1936 .{ }^{1}$ In Section III I shall try to suggest why this innovation effectively disappeared from view as Keynes' own work was transformed by others into Keynesianism or Keynesian economics. I shall argue that much of the Keynes-classics debate shifted the ground from the relationship between uncertainty and investment to the relationship between interest rates and investment. Section IV will take up a related question, why in fact Keynesianism was unable to discuss uncertainty problems. I will try to show that general equilibrium theory, the method of analysis which was used finally to adjudicate the Keynes-classics controversy, was not developed enough at the time of its use to pose the right questions. The concluding Section $\mathrm{V}$ will indicate the role of a few economists whose work has been consistent with Keynes' uncertainty motif.

\section{Keynes and Uncertainty}

It would be a herculean task, beyond the scope of this paper, to trace all the innovations that Keynes' work presented, their disappearance during the Keynesian counterrevolution, and their relative importance or unimportance in the current reevaluation of Keynes. ${ }^{2}$ Instead, I would like to pursue but one theme, Keynes' treatment of uncertainty, an innovation of sublime importance ignored for almost thirty years by most economists and still ignored by many.

Roy Weintraub is Associate Professor of Economics, Duke University.

1. The only other place this point is argued is G. L. S. Shackle, "Keynes and the Nature of Human Affairs," Weltwirtschaftliches Archiv, vol. 89 (1961).

2. Fortunately, two recent studies have posed a number of these issues: A. Leijonhufvud, On Keynesian Economics and the Economics of Keynes (New York, 1960), and P. Davidson, Money in the Real World (New York, 1973). 
A bit of history and biography might help put some later matters in perspective: "Between 1906 and 1911 Keynes was devoting all his spare time to the theory of Probability. . . . In 1912 other work supervened, and his treatise had to be left on one side until 1920, when he polished it up before its appearance in 1921. Thus it was his main work from the age of twenty-three to twenty-nine." ${ }^{3}$ This work attempted to carry out, for the theory of probability, the program initiated by Russell and Whitehead for mathematics, namely, to provide a logical foundation for the subject. At that time the only explicit theory which delineated the meaning of the proposition "the probability that $x$ is $y$ is $p$ " was that of Venn, which provided a relative frequency interpretation of probability statements. Such a theory asserted that the meaning of "the probability that $x$ is $y$ is $p$ " was that a large number of cases had been examined in which $x$ was $y$ and $x$ was not $y$, and $p$ was the proportion of the former in the total number of cases.

For Keynes, however, probability language was also applied to real choice situations beyond the casino. In assessing alternative plans for action, men are guided by their views of the most likely outcome. But outcomes are in the future and are not observed today. "The probability is .50 that it will rain tomorrow" is not a statement about worlds of possible tomorrows in half of which rain occurs, but rather an expression of our confidence in the fact that tomorrows are like yesterdays. More telling, however, is the observation that experiments like those with a roulette wheel are unavailable; we cannot get more knowledge of the future until it is here, but the decision whether to go to the beach tomorrow must be made today. ${ }^{4}$

In Chapter 8 of $A$ Treatise on Probability, ${ }^{5}$ Keynes rejected the relative frequency theory, since "if we allow it to hold the field, we must admit that probability is not the guide to life, and in following it we are not acting according to reason." ${ }^{\prime}$ Instead, Keynes suggested that probability was related, not to the balance between favorable and unfavorable evidence, but to the balance "between the absolute amounts of relevant knowledge and of relevant ignorance an accession of new evidence increases the weight of an argument.

3. R. F. Harrod, The Life of John Maynard Keynes (New York, 1966), p. 133.

4. The author most closely identified with Keynes on these matters of expectation and subjective probability is G. L. S. Shackle. In a large number of books, monographs, and articles he has presented this view and its ramifications to deaf-eared economists. We shall return to Shackle a bit later in our story.

5. The Collected Writings of John Maynard Keynes, VIII (London, 1973). The first edition of $A$ Treatise on Probability appeared in 1921.

6. Ibid., p. 104. Italics in original. 
New evidence will sometimes decrease the probability of an argument, but it will always increase its 'weight.' ${ }^{\prime}{ }_{7}$

Keynes' argument, then, was that to use probability to guide choice in matters of fundamental uncertainty one needed to discuss not only the probability but also the confidence one held in that probability. A high probability does not entail more certainty than a low one, since uncertainty is primarily characterized by a lack of confidence in probabilities high or low. One is only acting rationally in using probability as "a guide to life" if those probabilities are held with confidence. Consequently an economic agent ought not maximize expected payoffs, when each of an array of payoffs is assigned a probability number by the agent, if he has little confidence in those probabilities.

In modern parlance, it was Keynes' view that a major leap of faith is involved in treating situations characterized by uncertainty as situations involving only risk. ${ }^{8}$ Any choice now among future alternatives is thus fundamentally uncertain, since the future is logically unknowable. No sampling from the future is feasible to ascertain probabilities for future alternatives, so there is no way uncertainty problems can be reduced to problems involving risk.

Let us now jump in time to 1937. The General Theory had appeared the previous year, critics had begun to respond, and Keynes could deal with the central theme directly since his more detailed arguments had been presented:

I sum up, therefore, the main grounds for my departure [from the traditional theory] as follows: 1) the orthodox theory assumes that we have a knowledge of the future of a kind quite different from that which we actually possess. This false rationalisation follows the lines of the Benthamite calculus. The hypothesis of a calculable future leads to a wrong interpretation of the principles of behavior which the need for action compels us to adopt, and to an underestimation of the concealed factors of utter doubt, precariousness, hope and fear. ${ }^{9}$

7. Ibid., p. 77. Italics in original.

8. A choice is among risky alternatives if each alternative is specified by a known probability distribution, while an uncertain alternative is specified by an unknown distribution. If in fact the act of choosing destroys the choice set (as in a "crucial experiment"), some alternatives may be logically unknowable. It is this interpretation of "uncertain outcomes" which is stressed by Shackle in his own work.

9. "The General Theory of Employment," in Collected Writings of J. M. K., XIV, 121. Reprinted from the Quarterly Journal of Economics, Feb. 1937. 
Keynes here argued that in traditional theory situations involving uncertainty had been handled by probability tools appropriate for dealing with risk. Traditional theory assumed that one could maximize expected payoffs, even though expected values could not be confidently calculated. And yet individuals must act today; the effects of their choices will only be known in the future, but all economic activity undertaken at one time has intertemporal consequences. Economic man then must base decisions on something; that something is (1) the recent past and (2) what others are doing, but such a choice framework, "being based on so flimsy a foundation, . . . is subject to sudden and violent changes." 10

What relationship does this theme of the uncertainty matrix of economic decisions bear to the central thrust of the General Theory? To answer this, we need to consider just what Keynes felt he had done that was important:

My theory can be summed up by saying that, given the psychology of the public, the level of output and employment as a whole depends on the amount of investment. . . . [Although some other factors can affect output] it is those which determine the rate of investment which are more unreliable, since it is they which are influenced by our views of the future about which we know so little. ${ }^{11}$

Keynes argued, then, that employment depended on the level of output, and the level of output depended on the level of investment. In a formal sense investment, as the marginal efficiency of capital schedule, was the discounted value of the income the capital asset was expected to generate over its life; the discount factor was the interest rate on bonds, a "long". rate, since bonds and capital goods were perfect substitutes on the "long" end of the spectrum of asset-lives. ${ }^{12}$ Since, however, bond prices (and thus interest rates)

10. Ibid., p. 114.

11. Ibid., p. 121.

12. Leijonhufvud, supra n.2. There is another interpretation of the effect of interest rates on investment in Keynes, of more recent vintage, from Davidson, supra n.2, chap. 4. On this reading, there is never substitutability between bonds and capital goods as store-of-value assets. Instead the substitutability is between existing capital goods (whose present value is determined, at least notionally, on the spot market) and purchasing of new capital goods on the forward market (i.e., contract for future delivery). A change in the rate of interest changes the spot price (present value) of existing capital goods as a means of earning expected future income (not as a store of value). vis-à-vis the forward price of newly produced goods (with the same expected future income stream). On this reading, suggested by Davidson, uncertainty plays a similar role, the perturbation of the expected future income streams (of existing capital goods 
were primarily determined by speculative bullishness. and bearishness in the market, expected earnings determined investment, and such long-term expectations could not be analyzed by standard choice theory, since the earnings stream stretches well into the very uncertain future.

To this argument, the traditional economist would raise several objections. (1) The employment level so determined must be full employment, since an excess supply of workers at a wage would force wages down, thus bringing about full employment at a lower wage. (2) Even if an expectations collapse led to a decline in the quantity of investment, the supply of loanable funds (from savings which depended directly on the interest rate) would then exceed the demand (for investment purposes), so the excess supply would force the interest rate back down to equilibrium level.

Either of these two arguments (or both) were somewhat characteristic of the doctrines Keynes attacked. They each support the view of a capitalist market economy as a stable system; the price mechanism, in the various markets, would damp down deviations from equilibrium. The economy was viewed as self-regulated; so if unemployment existed, it must have been caused by rigidities or obstructions to the natural working of the market mechanism.

Keynes, of course, denied both arguments. On wage reduction he contended that someone in the labor market, buyers or sellers of labor services, had to lower real wages and both had control of money wages only. Although a decline in money wages might lower money prices and thus stimulate demand for goods and thus employment, money wages were income to wage earners and their demand for goods would fall. Overall, then, little could be expected from money wage cuts in a world of unemployment. On interest rates, Keynes denied that the volume of savings depended on the rate of interest to any real extent. Decisions to invest generated income that was spent, or saved. Expenditures on non-consumergoods had to equal income received but not spent on consumer goods, so measured savings always equaled measured investment.

Consequently, uncertainty (as it impinged primarily on the investment decision) was the culprit in involuntary unemployment. A collapse in expectations could lead to a fall in investment which, via the multiplier, would amplify the initial disturbance to reduce output and, thus, employment. Full employment was more a characteristic

instead of bonds). Both Leijonhufvud's and Davidson's interpretations can be accommodated by reading "asset market" for former's "bond market" and the latter's "stock market." 
of Heaven, where the future could never bring surprise; on this planet, where business plans for an unknown tomorrow by taking action today, unemployment is not unlikely.

One final point should be noted. The facts (1) that capital assets are long-lived, (2) that a desire to hold money is a measure of our distrust of the future, and (3) that production takes time are all facts which pertain to a world in which time is essential. We have seen how time and uncertainty were intermingled; the existence of the former necessarily entailed the latter. Keynes' system, then, was dynamic in the traditional sense of involving time in an essential manner; so if investment is volatile, because of uncertainty, no one level of output or employment might ever be maintained. It is in this sense that uncertainty can be called a disequilibrium phenomenon, and Keynes can be said to have dealt with disequilibrium problems. At any rate, it should be clear that adjustments to an equilibrium level of employment are meaningless in a world of uncertainty, for there might be no equilibrium in the sense of a maintained state of the system.

\section{The Development of Keynesianism}

We have seen in the preceding section how Keynes rejected traditional explanations of massive unemployment. In the view of some, however, Keynes' work was policy-oriented, directed to justifying large public expenditures to create employment. For such readers, the policy could be useful even if they chose to ignore the logic which reached the fiscal intervention conclusions. Other readers, of course, found themselves agreeing with positions Keynes called classical. ${ }^{13}$

Given Keynes' claim to have destroyed the traditional analysis, by showing its logical inconsistency, it was hardly a surprise when a number of economists began subjecting this claim to further scrutiny. Thus began the great Keynes-classics debate, the object of which was to set out Keynes' system and the neoclassical system in such a form that their major assumptions could be compared and their differing conclusions traced back to their different structure of interrelationships.

In a basic sense this should have been an easy task. Aggregate theorizing deals generally with but a few stylized markets: consumer

13. Keynes used the adjective "classical" to refer to economists from Ricardo to Pigou. Modern usage tends to identify post-marginalist writers as "neoclassicals" to distinguish them from Smith, Ricardo, Marx, Malthus, etc. 
goods, capital goods, labor, bonds, and money. One should have been able to do a supply-demand analysis in each market, under structural assumptions made by Keynes and the neoclassicals. What this amounts to, of course, is a general equilibrium study of networks of interrelated markets, with different assumptions and interrelationships characterizing the two systems. Unfortunately, however, both Keynes and his critics were steeped in the Marshallian tradition which abhorred such formal exercises; the dominant methodology was partial equilibrium analysis, where markets were studied one at a time under ceteris paribus assumptions. Yet it was precisely this sort of analysis that much of the General Theory broke from, and much of Keynes' theory was presented in an aggregate general equilibrium framework. ${ }^{14}$

Most of the early discussions about the General Theory concerned, then, the formalization of Keynes' system and also the formalization of the neoclassical system for comparative purposes. The difficulty in such a program was immediately apparent: while Keynes was on record, there was no canonical "traditional" model to be found. What combination of Marshall, Fisher, Pigou, Jevons, Wicksell, etc. was to be taken as the pre-Keynes dogma? The journals of the late 1930's and early 1940's boiled over as economists attempted to understand the new theory at the same time as they were trying to reconstruct just what it was that they had believed. For our purposes here, it suffices to focus on one aspect of this controversy: how the established view of Keynes' theory came into being, and how the uncertainty theme somehow got lost in the successive refinements.

Two of the most influential pieces in this literature may be taken as indicative of the controversy. The first, Hicks's "Mr. Keynes and the Classics" 15 appeared soon after the General Theory; the second.

14. For example, Keynes presented an argument that traditional economists could have used, but did not, to support money wage cuts: a fall in money wages would reduce marginal costs, and thus prices. Thus real money balances would increase, reducing the interest rate, and thereby stimulating demand for capital goods, total output, and employment. This argument runs through all the various submarket systems (General Theory, p. 258). Once again, terminology intrudes. Most British Keynesians would reject the assertion that Keynes ":did" general equilibrium theory (see, e.g., N. Kaldor, "The Irrelevance of Equilibrium Economics," Economic Journal, 1972. To those who identify general equilibrium theory with the Walrasian system and its Arrow-Debreu refinements, Keynes was indeed anti-equilibrium. Our usage of "general equilibrium theory" is a weaker one which merely suggests a "general systems" approach to theorizing. See, e.g., E. Roy Weintraub, General Equilib= rium Theory (London, 1974).

15. This paper was, originally, given orally at the Econometric Society meeting in 
Klein's The Keynesian Revolution, ${ }^{16}$ can almost be termed a summing-up of the debate after a decade had passed.

Hicks's purpose was quite clear: "If we can construct such a [typical classical] theory, and show that it does give results which have been commonly taken for granted, but which do not agree with Mr. Keynes' conclusions, then we shall at last have a satisfactory basis of comparison. ${ }^{17}$

For Keynes' General Theory, Hicks set up the following system (notation will here conform to modern usage):

$$
\begin{aligned}
& M=L(Y, r) \\
& I=I(r) \\
& I=S(Y) .
\end{aligned}
$$

Equation (1) set out the heart of Keynes' liquidity-preference theory of the demand for money: $M$, the money supply, was taken equal to demand for money, which was a function of $Y=$ output and $r=$ the interest rate. Equation (2) had the demand for investment equal to some function of the interest rate, and (3) savings depended on output. Equation (1) was thus an equilibrium statement of the money market, while (2) and (3) together gave an equilibrium in the goods market.

Graphically, this was the familiar IS-LM apparatus, although here all quantities were in money terms. Left out were explicit considerations of the labor market. Hicks, of course, had to analyze the inefficiency of money wage cuts in Keynes' system to draw a contrast to the "classical" view, but money wages did not even appear. Hicks thus argued that all quantities could just as well be written in terms of Keynes' "wage units," so that a fall in money wages would increase the supply of real money balances and shift the LM curve to the right. The effect on output and employment, Hicks argued, was inconsequential, since the LM curve was close to perfectly interest elastic ${ }^{18}$ at the low interest rates which characterized a depression. Thus monetary policy was useless, and wage cuts, which were analytically identical to an expansionary monetary policy, were likewise inefficacious. ${ }^{19}$

Oxford in August 1936, along with papers on the General Theory by Harrod and Meade. Kalecki, Marschak, and Shackle were in the audience. The paper appeared in Econometrica (1937) and is reprinted in J. R. Hicks, Critical Essays in Monetary Theory (Oxford, 1967). Page references are to this edition. in 1947 .

16. Page references are to the $2 \mathrm{~d}$ ed. (New York, 1966). The first edition appeared

17. Hicks, p. 127.

18. "nearly horizontal on the left," ibid., p. 135.

19. Hicks also argued that the LM curve is perfectly interest inelastic to the right, so an increase in investment will only serve to raise the interest rate, not output and 
Hicks's last sentence, which reads almost like an afterthought, is most instructive: "Further, all sorts of questions about depreciation have been neglected; and all sorts of questions about the timing of the processes under consideration." 20

"Depreciation" was a curious term to use; for Keynes, depreciation hardly mattered, although "user cost," those machine costs incurred through use (as opposed to normal wearing out), figured quite prominently as the mechanism by which entrepreneurial expectations of future price were translated into current output. Further, "the timing of the processes" can have little meaning in a certainty world. Time, and expectations of the future, are relevant in qualitative analysis only if uncertainty is present.

In short, Hicks was primarily concerned to show how Keynes accepted or rejected "classical" propositions derived from traditional models. Keynes' theory was thus cut down to "classical" form in order to elicit the contrast between models in which savings did or did not depend on interest rates and in which the demand for money depended entirely or only partly on output. Since "certainty." had never been stressed by traditional economists, it was not thought necessary to bring in Keynes' arguments about the effects of uncertainty.

Klein's The Keynesian Revolution had the advantage over Hicks of a decade's additional accumulated exegesis on Keynes; a much more detailed Keynesian model was the result. Further, the first attempts at forecasting using Keynes ideas had necessitated an agreed specification of the structural components of the "Keynesian" model, since the forecasts were, in effect, tests of the model itself.

In equations, Klein's Keynesian system appended to Hicks's version a labor market with the demand price for labor equaling labor's marginal product, which with competition was the real wage as

$$
N_{D}=f^{\prime}(N)=w / p
$$

(where $f(N)$ is a production function). The supply of labor was ruled by "money illusion," so workers were assumed to offer labor services in response to changing money wages as

$$
N_{S}=g(w) \text {. }
$$

Leaving the labor market aside, Klein argued ${ }^{21}$ that empirical work had shown a low interest elasticity of investment; conse-

employment (p. 136). This step set the stage for arguing that Keynes was really."classical."

20. Ibid., p. 142.

21. Klein, p. 88. 
quently the IS curve was close to vertical. Klein's specification explained the inability of money wage cuts to meliorate unemployment without having to invoke the liquidity trap. With a fall in money wages, the price level would fall, increasing real money balances. The rightward shift in the LM curve would have little, if any, effect on real output and employment if the IS curve were nearly vertical. Klein concluded this argument as follows:

In order to show that full employment is not automatic in a perfect world subject to Keynesian conditions, it is necessary to assume nothing whatsoever about rigidities in the system, but only to make plausible assumptions about the interest-inelasticity of certain basic relationships. ${ }^{22}$

Yet this statement is most puzzling, for while it chided those who argued that Keynes' only contribution was to assert that money wages were rigid downward, it nonetheless did suggest that some other price "signal," the interest rate, did not convey information.

To fully appreciate this point, let us examine in more detail Klein's "Keynesian" demand for capital goods equation:

The individual firm tries to maximize its expected profits subject to the constraint that it operates within the fremework of certain technological conditions. The profits depend upon prices, sales, and the use of factors . . . we make the further assumptions that the expected national income depends upon the most recently observed levels of national income (how else can expectations be formed?) and that there is only one price level in the system. . . . ${ }^{23}$

Klein then suggested that since the future is uncertain, a risk component must be added to the interest rate to get the discount rate for valuing future profits. Consequently the actual interest rate might not affect investment very much; investment would remain interest inelastic.

Return now to Klein's full model. There were three markets: for goods, for money, and for labor; and three prices: of goods, of bonds, and of labor. As Leijonhufvud has shown ${ }^{24}$ this kind of

22. Ibid., p. 89.

23. Ibid., pp. 62, 63.

24. Leijohufvud, supra n.2, chap. 3. This paragraph and the next follow Leijonhufvud's interpretation. An alternative reading, following Davidson (see n.12 above), could also be provided. If new investment purchases forward were a substitute for spot purchases of existing capital assets, it is the market for capital assets which is missing. The interest rate discounts the prospective earnings stream of these 
model had "lumped" consumer goods and capital goods together, and suppressed the bonds market. But if capital assets and "long" bonds were substitutes, as they were for Keynes, a major determinate of the quantity of capital demanded is the price of substitute assets. Since the demand price of a capital good is, by the MEC schedule, inversely proportional to the interest rate, what Keynes argued is that an increase in the interest rate subsumed a fall in bond prices and thus, by substitutability, a fall in the quantity of capital assets demanded. Thus the investment demand schedule was interest elastic.

Klein effectively had no price for capital goods in his system ("there is only one price level"); the bond market is missing, and thus the interpretation of the interest rate is anomalous. For Keynes a collapse in expectations, because they are based on uncertainty, is a result of the speculative nature of the bond market. Fluctuations in bond prices were discussed at length in Keynes' General Theory Chapter 14 on "the State of Long Term Expectations," in which bearishness (and bullishness) combined to push down (or up) bond prices, and thus push interest rates up (or down). If a guide to the future, and the basis of the investment decision, is "what others are doing," and they are "doing it" in the bond market, investment activity will indeed be volatile.

Why did Keynes' view of the effect of uncertainty get transmogrified into the interest inelasticity of investment? There are two primary skeins to this development.

First, there was a theoretical need to demonstrate two "Keynesian," or anti-classical, propositions: the inefficacy of monetary stimulation to combat massive unemployment and the inability of money wage cuts to increase employment. Neglecting Keynes' argument that a fall in money wages reduces income directly and, through the multiplier, reduces employment, explanations had to be sought for both propositions in the structure of the IS-LM curves. Either the LM curve was highly elastic (the liquidity trap), or the IS curve was highly inelastic (so the monetary stimulus would be ineffective), or both.

Second, the advent of econometric forecasting, using yearly or quarterly data, dictated that an interest rate be found to use in the

assets. Overall, then new investment purchases will be influenced by the interest rate as long as uncertainty does not rule the equities market. The next paragraph of the text can also be given this alternative reading. See, in addition to Davidson, Money, idem, "Disequilibrium Market Adjustment: Marshall Revisited," Economic Inquiry, June 1974, and G. L. S. Shackle, The Years of High Theory (Cambridge, 1967), pp. 149-52. 
models. The standard choice was an average or index of AAA bond rates, or a prime rate, which is not an effective measure of the opportunity cost of a long capital asset. Using such a rate almost forces the conclusion of interest inelasticity of investment.

We may draw the tentative conclusion that the neglect of uncertainty in the system of the Keynesians was based, primarily, on their more immediate attempt to justify "anti-classical" conclusions. In large measure they adopted an analytic framework only partially consistent with the General Theory; when that framework did not produce the "correct" conclusions, emendations were made to Keynes' own analysis. The literature is full of arguments to the effect that Keynes had never really worked out, or did not understand, his own theory; ${ }^{25}$ thus a student's reading of Keynes was positively discouraged ${ }^{26}$ by many Keynesians on the grounds that more recent work had cleared up the many inconsistencies.

\section{The Development of General Equilibrium Theory}

We have seen that Keynes' major ideas were presented, and later formalized, by a system of interrelated markets; though these markets were aggregative in structure, they did form a general equilibrium system. To discern more precisely the basis of Keynes' model, one should also examine the microeconomic foundations of the macroeconomic theory. The choices made by individual consumers and individual firms should provide much the same information about the structure of the theory as the more aggregated interpretations, especially since the individual behavior can be worked out first, then explicitly aggregated. For example, one could suppose that firms hire labor to produce output, sum over all firms, and have total employment determined from those microeconomic considerations which led to the hiring decision.

Except for the work of Walras, Pareto, and others in the Lausanne tradition, little progress had been made in general equilibrium theory until the late 1930's. Hicks's Value and Capital, which was published in 1939, reinvigorated the Walrasian method and set out an explicit agenda for investigating macroeconomic problems with microeconomic tools: "I believe I have had the fortune to come upon a method of analysis which is applicable to a wide variety of economic problems ... the method ... is, perhaps most illuminat-

25. Klein.

26. Leijonhufvud. 
ing when it is applied to the complex problems (such as those of trade fluctuations) $\ldots .{ }^{27}$

The care, lucidity, and precision of Hicks's book captured the imagination of many economists who had difficulty following the arguments of the highly aggregated Keynes-classics controversy. A firm, at least, could be understood concretely, whereas the bond market already incorporated several layers of abstraction. In Hicks's hands, the general equilibrium approach seems so very sensible; not surprisingly, other economists began to mine this territory as well:

This monograph presents a systematic investigation of the effect of price flexibility, particularly flexibility of prices of factors of production, upon employment and economic stability. According to traditional economic doctrine, unemployment is entirely due to the rigidity of factor prices. . . . Lord Keynes maintains that, under certain conditions, changes in money wage rates have no effect upon employment but influence only the level of product prices. ... The diversity of opinions can be distangled only by considering the problem within the framework of the general theory of economic equilibrium. ${ }^{28}$

Thus Lange began his important investigation of macroeconomics, utilizing the apparatus developed by Hicks. The increased interest in the development of general equilibrium theory was due in large measure to the Keynes-classics debate; in Lange, and as we shall see later in Patinkin, it was argued that the neoclassical model neglected to treat money in a consistent and sensible fashion, and Keynes was given credit for pointing this out at an aggregate level. If, however, the neoclassical model was "repaired" with a "correct" treatment of money (and bonds), it could be shown that the Keynesian system was but a special case of the neoclassical one. ${ }^{29}$

Before we continue with the story, it is necessary to say a few words about the structure of this Walrasian theory, for we shall argue later that the structuring of the problem in Walrasian terms necessarily precluded consideration of uncertainty problems.

Beginning with preferences of individuals, and a budget constraint which had the household spend (or save) income received from sale of factor (labor) services and rental of capital goods, a demand function could be generated assuming constrained "utility"

27. J. R. Hicks, Value and Capital (Oxford, 1939), p. 1.

28. O. Lange, Price Flexibility and Employment (Bloomington, Ind., 1944), p. 1.

29. This emended neoclassical (Walrasian) model is called, by some, the neoneoclassical model. This usage will be avoided here. 
maximization. A supply curve for factor services could also be generated from the work-leisure preferences of individuals and a time constraint. The firm had preferences, generally indicated by profit levels; assuming a given technology and factor prices, supply of goods could be determined from profit maximization, and derived demand curves for factors could be developed under competitive conditions. In addition, since an autonomous source determined the money supply, and real money balances provided services to households, a demand curve for money could be created again on utility maximization assumptions. The bond market reflected a supply of bonds issued by firms or government, and a demand for these bonds as income-generating assets.

The major problem examined using such a system was the possibility that a set of product prices and factor prices would exist which equilibrated the independent desires of all the economic agents. In other words, did a price system exist such that, if all individuals optimized taking this price system as given, all markets would clear? Further, it was of interest to know whether such a price system, if it existed at all, was the only such system. Finally, theorists asked whether, if such a set of equilibrium prices existed, and at some time prices happened to be different, there were market forces which would push the existing prices toward the set of market clearing prices. These three questions were the problems of existence, uniqueness, and stability of the competitive equilibrium. If such an equilibrium existed, for example, there was a wage rate at which the labor market would clear, and unemployment could not be a maintained state if market forces existed to mitigate the excess labor supply. If sensible conditions could be developed under which a unique competitive equilibrium would be stable, then Keynes' system must have been an aberrant special case; it was an important case to be sure, but one of little theoretical importance, since it lacked generality.

This then was the research program sketched out by Hicks in Values and Capital. In 1939, however, there were no theorems at all about the existence, uniqueness, or stability of a competitive equilibrium. It is important to understand the historical development here, for it is often argued that general equilibrium theory had nothing to contribute to important macroeconomic questions. While this complaint has some merit, it will seem to be so for reasons quite different from those suggested at the time of the Keynes-classics debate. ${ }^{30}$ 
One of the first economists to push out the Hicksian frontier was Samuelson. In his Foundations of Economic Analysis, ${ }^{31}$ which appeared in 1947, there was a clear statement of the interrelationships among concepts of stability, and an argument which suggested that until stability could be proved for a system, few comparative static propositions could be well-posed. This conjecture, called the Correspondence Principle, accelerated attempts to (a) formalize and (b) prove theorems about general equilibrium systems, since an implication of the Principle was that unless a model like Keynes's was well-behaved at the microeconomic level, one could have little faith in the then standard curve-shifting arguments.

It was not until 1954 that the existence problem for a competitive economy could be called settled. Arrow and Debreu ${ }^{32}$ developed a proof in that year which could be used to justify working with Walrasian systems. It took four more years, however, to develop stability theorems: credit for this effort is shared by Arrow and Hurwicz. ${ }^{33}$

Why was there such a hiatus in formalizing, with general equilibrium analysis, the macroeconomic questions that so excited economists in the late 1930's? The answer is so simple that it is seldom appreciated: general equilibrium theory turned out to be very difficult. While macroeconomists were suggesting that general equilibrium theory had not produced a sensible foundation for Keynesian theory, or were arguing whether Lange had "really" crystallized the Keynesian vision, the mathematics necessary to adjudicate the rival claim was just in the process of being created; ${ }^{34}$ the application of that mathematics to economics would take even longer. ${ }^{35}$

To return again to our main theme, we can find a quintessential

argument, N. Kaldor's polemic "The Irrelevance of Equilibrium Economics," Economic Journal, 1972, seems to be misguided. See the response by F. H. Hahn, On the Notion of Equilibrium in Economics (Cambridge, 1973).

31. (Cambridge, Mass., 1947).

32. K. Arrow and G. Debreu, "Existence of an Equilibrium for a Competitive Economy," Econometrica, July 1954.

33. K. Arrow and L. Hurwicz, "On the Stability of a Competitive Equilibrium, I," Econometrica, Oct. 1958.

34. The major tool used to solve the existence problem, a fixed point theorem, was developed in 1941 by S. Kakutani, "A Generalization of Brouwer's Fixed Point Theorem," Duke Mathematical Journal.

35. The development of stability theorems makes for a curious story which should be examined by some future historian of science. The major work was done by the Russian mathematician A. M. Liapunov, whose original Mémoire was published in Russian in 1892. Although a French translation was published in 1907, this work had little effect on the stability-instability discussions of economists until the 1950's. 
statement of the Keynes-classics debate, in a full-dress general equilibrium setting, in Patinkin's Money, Interest, and Prices. ${ }^{36}$ The first edition, which appeared in 1956, set out a "repaired" neoclassical model which, when aggregated, had the usual quantity theory of money implications without the equation of exchange. In particular Patinkin showed that price flexibility did indeed produce a full employment equilibrium position. Keynes was firmly put down as having analyzed a special case in which labor market rigidities prevented competitive results from obtaining. Patinkin's immense scholarship, however, led him to hedge this flat statement with an important caveat $^{37}$ to the effect that Keynes may have been concerned with disequilibrium and dynamic problems which involved points "off" the curves which modeled the labor market. (It is only recently, however, that this point has come to be considered important, as we shall see below.)

What kind of theory was it, then, that could be aggregated into a system in which Keynes became an egotistical nontheorist claiming to have a "general" theory? What was it about the Walrasian system that forced such a conclusion and, in such an awesome mathematical edifice, seemed to leave no niche in which mere economists could erect statues to Keynes?

Although there are a number of answers often given to this question, two in particular have seemed to commend themselves to the professional temper, and both pertain to the inability of the Walrasian system to deal with uncertainty problems.

The first argument, by far the most widely held among critics of the Walrasian system, is that the Arrow-Debreu model requires a large number of futures markets which simply do not exist. ${ }^{38}$ In particular, any model of the economic system in which economic agents must frame plans today to cover acts which must be undertaken tomorrow requires, if expectations are to be fulfilled (which is one characteristic of equilibrium), futures markets in goods. The only way an investment project, then, could be undertaken by a rational entrepreneur would be under the assumption that he could contract in an existing market to sell off that capital asset if its return was less than expected. If uncertainty leads one to hedge, such speculative activity in spot markets may misallocate current resources and

36. New York, 1956.

37. P. $313 \mathrm{ff}$.

38. Further, futures markets involve mutually contradictory expectations held by different parties. They can alter the effects which surprising, disconcerting, and unthought-of events will have, but they do not eliminate the essential lack of knowledge of the future. 
thus lead to unemployment. Allocative efficiency thus requires a plethora of futures markets in all goods and services about which uncertainty exists. This is a major point developed in the recent treatise by Arrow and Hahn, who conclude "that the Keynesian revolution cannot be understood if proper account is not taken of the powerful influence exerted by the future and past on the present and by the large modifications that must be introduced .... if the requisite futures markets are missing." 39 This is not all, however; for even if there were futures markets for all concurrently existing goods and services, there would still be problems, since futures markets for all possible future goods and services cannot logically be analyzed by any choice theory which presumes "given preferences."

The second argument is essentially dynamic in nature as opposed to the first, which is really a "nonexistence of equilibrium" argument. The only mechanism that forces arbitrary prices to equilibrium prices in the Walrasian theory is the tatonnement. This adjustment rule requires that no trades be actually consummated until equilibrium is attained, since disequilibrium trading redistributes the income that is taken as "given" in deriving the demand curves. As Hahn has noted, however, in all real economies "the equilibrium path is strewn with the remnants of past mistakes." 40 Real capitalist economies require decisions to be made, and exchange to occur, when both parties can benefit. Such observations have led to the study of non-tatonnement processes in which trades can occur at any prices as long as the resulting allocation is Pareto-superior. Recent work has shown, however, that a speculative element is present in such a process, since money mediates in exchange. ${ }^{41}$ That is, party A may contract with party B for an exchange of goods for money, but since party A must pay by first selling labor services to party C, A's contract with B contains a speculative element, namely, A's ability to actually realize income from sale of labor services. In brief, the speculative nature of non-tatonnement processes is produced by fundamental uncertainty about the future, and information about that future cannot exist today.

To sum up this section, we have seen why there was an attempt to pose Keynes' system in general equilibrium terms. Such an exer-

39. K. Arrow and F. H. Hahn, General Competitive Analysis (San Francisco, 1971).

40. F. H. Hahn, "Some Adjustment Problems," Econometrica, Jan. 1971.

41. This is the nub of Clower's Dual-Decision Hypothesis, Cf. R. Clower "The Keynesian Counterrevolution: A Theoretical Appraisal," in The Theory of Interest Rates, ed. F. H. Hahn and F. Brechling (New York, 1965). 
cise necessitated turning Keynes even further into a Keynesian who ignored uncertainty, because the Walrasian framework of general equilibrium theory was too narrowly circumscribed by (a) its reliance on current markets and (b) its inability to deal with essentially disequilibrium phenomena.

\section{A Concluding Note}

Although many British economists taught and wrote about Keynesian topics from 1936 on, few of them really deserve the label "Keynesian" as it is applied to certain American economists by Leijonhufvud. Mrs. Robinson, Kaldor, Harrow, Kahn, and others were too well-versed in the General Theory to accept the modernized, expurgated version sold without the monetary theory ingredients. The proposition could be defended, in fact, that "Keynesianism" was primarily an American phenomenon; the influence of Samuelson's Economics textbook on the thinking of economists has yet to be studied.

Despite the work of Keynes' junior disciples in England, it is not too hard to understand some of the reasons why there was no successful systematic revision of the dominant brand of U.S. Keynesianism until Leijonhufvud wrote in 1968. The problem could be rephrased in a more illuminating manner by breaking it into two queries: (1) Was there anyone before Leijonhufvud whose "revisionism" failed to impress? And (2) why were economists more willing in 1968 to accept reinterpretations of Keynes?

On the first issue, I am especially aware of one set of pre-1968 attacks on IS-LM Keynesianism: beginning in $1958 \mathrm{~S}$. Weintraub ${ }^{42}$ was examining an alternative aggregate supply/aggregate demand framework for interpreting the General Theory. Such analysis was especially useful in macro-distribution analysis, but its underpinnings were distinctly Marshallian-the price theoretic content of the aggregate supply curve was not Walrasian in outline or detail. Such work, however, could not break the habits that a reasonably well developed literature on the Keynesian revolution had formed. After 1968 the fact of simultaneous unemployment and inflation, and the challenge of the "monetarists" to the dominant "Keynesianism," forced a serious reappraisal of Keynes among American economists.

42. See especially his An Approach to the Theory of Income Distribution (Philadelphia, 1958); Classical Keynesianism, Monetary Theory, and the Price Level (Philadelphia, 1961); and Some Aspects of Wage Theory and Policy (Philadelphia, 1963). A macro textbook, presenting a number of these ideas, appeared in 1964: P. Davidson and E. Smolensky, Aggregate Supply and Demand Analysis (New York, 1964). 
And as we have shown in the preceding section, it was not until the late 1960's that the general equilibrium theorists began to question the viability of the Walrasian foundation of Keynesianism. This confluence of events and theory has provoked the current revival of interest in all of Keynes' writings.

Our story should not be permitted to end with the suggestion that an important innovation like Keynes' treatment of uncertainty can be lost for years and only rediscovered when the theory for which it had been developed begins to explain little in its absence. ${ }^{43}$ Indeed, there has been one economist, G. L. S. Shackle, whose professional career has been devoted to these crucial themes of economics and time, expectations, and uncertainty.

Even in 1938, when he wrote Expectations, Investment, and Income ${ }^{44}$ Shackle was grappling with the formulation, elucidation, and solution to those problems of uncertainty and macroeconomics which Keynes had broached but left unresolved. Indeed, that 1938 work was an attempt to graft the Swedish ex ante/ex post framework for handling time and expectations onto a Keynesian comparative statics model.

Through the years Shackle has reintegrated such expectationscum-uncertainty themes with more traditional Keynesian economics ${ }^{45}$ and developed, with his "logic of focus-values," a machine for analysis that is consistent with the fragmentary insights Keynes himself provided in the 1937 Quarterly Journal of Economics article. Consequently an interesting test of the merit of the argument of the preceding sections will be to see whether the writings of G. L. S. Shackle become more important to macroeconomists over the next few years.

43. For the importance of this "pure theory" issue to matters of current policy, see "Radical Keynesians" in Business Week, May 12, 1975.

44. Oxford, 1938.

45. For Shackle's most direct and lucid summary of the issues involved, see Keynesian Kaleidics (Edinburgh, 1974). For an extensive bibliography of his writings see C. F. Carter and J. L. Ford, eds., Uncertainty and Expectation in Economics: Essays in Honour of G. L. S. Shackle (Oxford, 1972).

I have had helpful comment on earlier drafts of this article from Richard Froyen, Paul Davidson, Martin Bronfenbrenner, and G. L. S. Shackle. 